\title{
MicroRNA-21 Expression, Serum Tumor Markers, and Immunohistochemistry in Canine Mammary Tumors
}

\author{
Noha Y. Salem \\ Cairo University Faculty of Veterinary Medicine \\ Eman S. Ramadan \\ Cairo University Faculty of Veterinary Medicine \\ Ibrahim A. Emam \\ Cairo University Faculty of Veterinary Medicine \\ Naglaa A AbdElKader ( $\square$ naglaa_abd.elkader@cu.edu.eg ) \\ Cairo University Faculty of Veterinary Medicine https://orcid.org/0000-0001-6695-4163 \\ Haithem A. Farghali \\ Cairo University Faculty of Veterinary Medicine \\ Marwa S. Khattab \\ Cairo University Faculty of Veterinary Medicine
}

\section{Research article}

Keywords: Canine mammary tumor, CEA, CA 15-3, Immunohistochemistry, miRNA-21

Posted Date: February 25th, 2021

DOI: https://doi.org/10.21203/rs.3.rs-272047/v1

License: (c) (i) This work is licensed under a Creative Commons Attribution 4.0 International License. Read Full License 


\section{Abstract}

Background: Canine mammary tumors (CMTs) are one of the most common malignancies in dogs and are associated with significant mortality. Serum tumor markers and non-coding microRNAs have recently gained widespread popularity in human oncology studies. We aimed to investigate the expression of microRNA-21 (miR21), changes in serum tumor markers (CEA and CA 15-3), and immunohistochemistry in CMTs diagnosed by clinical examination, radiology, and histopathology. This study enrolled 17 female dogs: 10 with mammary tumors and seven controls without tumors. Blood samples were collected to measure miR-21, CEA, and CA 15-3, and histological samples were prepared for histological grading and immunohistochemistry.

Results: CA 15-3 was elevated in all animals, whereas CEA levels showed no change compared with controls. miR-21 was upregulated 12.84fold in animals with CMT. The most frequently recorded CMT was mixed type. Myoepithelial cells were identified by P63 immunoreactivity, but not SMA. High expression of miR-21 was observed with positive vimentin immunoreactivity, indicating a mesenchymal origin of the tumor cells.

Conclusion: The present study showed that miR-21 was elevated to a greater extent than CA 15-3 (12.84-fold vs. threefold). Mixed-type tumors with positive vimentin immunoreactivity showed the highest miR-21 levels. These findings support the hypothesis that miR-21 may be a more sensitive, noninvasive indicator for CMT.

\section{Background}

Canine mammary tumors (CMTs) are one of the most commonly observed tumors in female dogs and contribute to significant mortality [13]. It was postulated that up to $81 \%$ of CMTs are malignant [4].

Diagnosis of mammary tumors require a constellation of tests, laboratory assessment for cancer using fine-needle aspiration, and histopathology. Ultrasonography and radiography may be used for further confirmation $[5,6]$. Despite the availability of a wide range of diagnostic modalities for cancer, no single modality is foolproof for the identification of cancer [7].

Many histological classification systems have been proposed for CMTs [8]. A histological staging system for canine mammary carcinomas was recently published and provides a strong prognostic factor for canine mammary carcinoma. The histological stage of this system includes disease-free-interval, overall survival, and specific survival of dogs with mammary carcinoma [9]. The types of cells in the carcinoma or malignant myoepithelioma can be identified using immunohistochemistry markers such as CK8, CK18, CK19, and CK7 for epithelial cells and CK5, CK6, CK14, CK17, smooth muscle actin, calponin, vimentin, and p63 for basal/myoepithelial cells. Cell differentiation markers have been investigated to elucidate the histogenesis of tumors, particularly mixed-type mammary carcinoma, which is common in dogs [10].

Tumor markers are products of cellular metabolism that are elevated due to malignant transformation [11]. The most widely used serum markers in breast cancer are cancer antigen $15-3$ (CA $15-3$ ) and carcinoembryonic antigen (CEA). Measurement of these markers is relatively inexpensive and requires a less invasive method of sample collection compared with immunohistochemical tests, which have been used in veterinary medicine [12].

Studies in human medicine have shown characteristic expression profiles of miRNA in tumors [13]. MicroRNAs (miRNAs) are clusters of small non-coding RNA that play an essential part in posttranscriptional gene expression as imperative regulators [14, 15]. Several miRNA species have been identified to be involved in human breast cancer development, including miR-21, miR-145, and miR-210 [16-18].

There is an increasing requirement for a rapid and accurate test to confirm the presence of disease in a clinical setting. New serum tumor markers and novel miRNAs could be used as a rapid diagnostic test; however, it is not yet clear which is more superior. Few studies have investigated the expression of miR-21 in CMTs; therefore, the present study investigated miR-21 expression compared with changes in serum tumor markers (CEA and CA15-3), and the use of immunohistochemistry in typing CMTs and identifying type of cells relative to expressed miR-21.

\section{Results}

\section{Preliminary patient data}

The median age range for affection was 9 years (range, 7-15 years). The German Shepherd breed appeared to be overrepresented in the present study, accounting for $40 \%$ of all dogs (Table 1). Figures 1 and 2 show clinical images of the dogs. 
Table 1

Clinical Data of each clinical case of mammary tumor

\begin{tabular}{|c|c|c|c|c|c|c|}
\hline $\begin{array}{l}\text { Case } \\
\text { no }\end{array}$ & breed / Age & Tumor location & size & Lymph node & Metastasis & $\begin{array}{l}\text { Surgery and } \\
\text { pathology }\end{array}$ \\
\hline 1 & $\begin{array}{l}\text { German } \\
\text { shepherd / } 8 \text { year }\end{array}$ & $\begin{array}{l}\text { Big tumor in the inguinal } \\
\text { mammary gland with inguinal } \\
\text { hernia }\end{array}$ & $7 * 5 \mathrm{~cm}$ & Enlarged & $\begin{array}{l}\text { Not } \\
\text { metastatic }\end{array}$ & Surgery \\
\hline \multirow[t]{3}{*}{2} & \multirow[t]{3}{*}{ Griffon /14 year } & Right inguinal & $7 * 6 \mathrm{~cm}$ & \multirow{2}{*}{$\begin{array}{l}\text { Enlarged right } \\
\text { inguinal lymph } \\
\text { node }\end{array}$} & \multirow{3}{*}{$\begin{array}{l}\text { Not } \\
\text { metastatic }\end{array}$} & \multirow{3}{*}{$\begin{array}{l}\text { Tumor progressed } \\
\text { and enlarged and } \\
\text { animal dead }\end{array}$} \\
\hline & & Left inguinal & $4 \star 4 \mathrm{~cm}$ & & & \\
\hline & & Right caudal thoracic & $3 * 2 \mathrm{~cm}$ & $3 \star 2 \mathrm{~cm}$ & & \\
\hline \multirow[t]{2}{*}{3} & \multirow[t]{2}{*}{$\begin{array}{l}\text { German } \\
\text { shepherd } / 7 \\
\text { years old }\end{array}$} & Right inguinal & $9 * 7 \mathrm{~cm}$ & $\begin{array}{l}\text { Enlarged right } \\
\text { inguinal lymph } \\
\text { node }\end{array}$ & \multirow[t]{2}{*}{$\begin{array}{l}\text { Not } \\
\text { metastatic }\end{array}$} & \multirow[t]{2}{*}{ Surgery } \\
\hline & & & & $4.5 \star 4 \mathrm{~cm}$ & & \\
\hline 4 & $\begin{array}{l}\text { Labrador } / 7 \\
\text { years old }\end{array}$ & $\begin{array}{l}\text { Left caudal abdomen + left } \\
\text { inguinal }\end{array}$ & $11 * 3 \mathrm{~cm}$ & & $\begin{array}{l}\text { Not } \\
\text { metastatic }\end{array}$ & Surgery \\
\hline 5 & $\begin{array}{l}\text { mongrel dog/ } 7 \\
\text { years old }\end{array}$ & right cranial abdomen & $3 * 4 \mathrm{~cm}$ & & $\begin{array}{l}\text { Not } \\
\text { metastatic }\end{array}$ & \\
\hline \multirow[t]{3}{*}{6} & \multirow{3}{*}{$\begin{array}{l}\text { German } \\
\text { shepherd } / 9 \\
\text { years old }\end{array}$} & \multirow{2}{*}{$\begin{array}{l}\text { Right caudal abdomen + right } \\
\text { inguinal }\end{array}$} & $7 * 3 \mathrm{~cm}$ & & \multirow[t]{3}{*}{$\begin{array}{l}\text { Not } \\
\text { metastatic }\end{array}$} & \\
\hline & & & $3 * 1.5 \mathrm{~cm}$ & & & \\
\hline & & 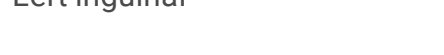 & $6 * 2 \mathrm{~cm}$ & & & \\
\hline 7 & $\begin{array}{l}\text { Golden retriever / } \\
\text { 9years }\end{array}$ & left inguinal & $5 \star 2 \mathrm{~cm}$ & & $\begin{array}{l}\text { Not } \\
\text { metastatic }\end{array}$ & \\
\hline 8 & $\begin{array}{l}\text { German } \\
\text { shepherd } \\
\text { /10years }\end{array}$ & $\begin{array}{l}\text { Left cranial abdomen + caudal } \\
\text { abdominal }\end{array}$ & $\begin{array}{l}7 * 3 \mathrm{~cm} \\
\text { with } \\
\text { ulceration }\end{array}$ & & $\begin{array}{l}\text { Not } \\
\text { metastatic }\end{array}$ & \\
\hline 9 & $\begin{array}{l}\text { Rottweiler } / 9 \\
\text { years }\end{array}$ & Left caudal abdomen & $4 * 5 \mathrm{~cm}$ & & $\begin{array}{l}\text { Not } \\
\text { metastatic }\end{array}$ & \\
\hline 10 & $\begin{array}{l}\text { North American } \\
\text { shepherd } \\
\text { /15years }\end{array}$ & Left inguinal & $5 \star 3.5 \mathrm{~cm}$ & & $\begin{array}{l}\text { Not } \\
\text { metastatic }\end{array}$ & \\
\hline
\end{tabular}

\section{Hematology And Tumor Markers}

Hematological evaluation revealed a non-significant reduction in red blood cells, packed cell volume (PCV), and hemoglobin (Hb), along with a significant reduction in TLC. Significant elevation in thrombocytes was recorded in animals in the disease group compared with the controls (Table 2). 
Table 2

Hematologic findings in bitches with mammary tumor and control group

\begin{tabular}{|c|c|c|}
\hline Parameters/unit & Control group & Diseased group \\
\hline RBCs count $\left(10^{12} / \mathrm{L}\right)$ & $6.80 \pm 0.30$ & $6.04 \pm 0.21$ \\
\hline $\operatorname{PCV}(I / I)$ & $0.43 \pm 0.02$ & $0.40 \pm 0.01$ \\
\hline $\mathrm{HB}(\mathrm{gm} / \mathrm{L})$ & $144.05 \pm 7.54$ & $136.66 \pm 4.26$ \\
\hline $\operatorname{MCV}(\mathrm{fl})$ & $62.81 \pm 1.64$ & $68.12 \pm 2.61$ \\
\hline $\mathrm{MCH}(\mathrm{pg})$ & $21.14 \pm 0.50$ & $22.99 \pm 0.80$ \\
\hline $\mathrm{MCHC}(\mathrm{gm} / \mathrm{L})$ & $337.31 \pm 8.47$ & $340.91 \pm 6.77$ \\
\hline Platelets $\left(10^{9} / \mathrm{L}\right)$ & $184.00 \pm 7.11$ & $271.90 \pm 7.26^{\star \star \star}$ \\
\hline $\mathrm{N}(\%)$ & $63.14 \pm 1.45$ & $62.15 \pm 4.80$ \\
\hline L (\%) & $23.28 \pm 1.76$ & $26.80 \pm 4.76$ \\
\hline M (\%) & $7.28 \pm 0.74$ & $6.78 \pm 0.82$ \\
\hline$E(\%)$ & $4.85 \pm 0.80$ & $4.12 \pm 0.55$ \\
\hline WBCs $\left(10^{9} / \mathrm{L}\right)$ & $11.18 \pm 0.80$ & $8.06 \pm 0.76^{\star *}$ \\
\hline
\end{tabular}

Evaluation of serum tumor markers showed significant elevation in CA 15 - 3 in disease group animals compared with controls (Table 3 ).

Table 3

Serum levels of CEA and CA $15-3$ in bitches with mammary tumor and control group

\begin{tabular}{|lll|}
\hline Parameters/unit & Control group & Diseased group \\
\hline CEA $(\mathrm{ng} / \mathrm{mL})$ & $0.14 \pm 0.03$ & $0.15 \pm 0.05$ \\
\hline $\mathrm{CA} 15-3(\mathrm{ng} / \mathrm{mL})$ & $1.33 \pm 0.10$ & $3.76 \pm 0.43^{\star * \star}$ \\
\hline Data are represented as mean $\pm \mathrm{SE}, * \mathrm{P}$ value $\leq 0.05$ considered significant, SPSS program version16.00 independent sample t test. \\
\hline
\end{tabular}

\section{Mir-21 Expression}

miR-21 was upregulated 12.84-fold in animals in the disease group compared with the controls (Table 4).

Table 4

Expression of MiR-21 in bitches with mammary tumor and control group

\begin{tabular}{|llll|}
\hline Group & U6 & MiR-21 & Fold change \\
& CT & CT & $(2-\Delta \Delta \mathrm{CT})$ \\
\hline Control group & 19.57 & 23.58 & - \\
\hline Canine mammary tumor & 20.71 & 21.04 & $12.84^{\star \star \star}$ \\
\hline
\end{tabular}

\section{Radiology}

Radiographic examinations showed no signs of lung metastases or thorax chest lesions in any of the animals with CMT (Figs. 3 and 4).

\section{Histology And Immunohistochemistry}


Microscopy of the canine tumors revealed two tubular carcinomas, micropapillary carcinoma, ductal carcinoma, two mixed-type carcinomas, two complex-type carcinomas, low-grade fibromyxoid sarcoma, and mammary sarcoma. The histological gradings are shown in Table 5. In well-differentiated complex carcinoma, the neoplastic cells appeared large hepatoid cells with eosinophilic cytoplasm. They were pleomorphic with prominent nucleoli, often vacuolated and arranged in an acinar pattern. Neoplastic cells were separated by delicate fibrovascular stroma, and mitosis was frequently observed in the these cells (Fig. 5a).

Table 5

The scores and grades of the neoplasms recorded in this study

\begin{tabular}{|c|c|c|c|c|c|c|}
\hline Type of neoplasm & $\begin{array}{l}\text { Number of } \\
\text { animals }\end{array}$ & $\begin{array}{l}\text { Score of tubule } \\
\text { formation }\end{array}$ & $\begin{array}{l}\text { Score of } \\
\text { mitosis }\end{array}$ & $\begin{array}{l}\text { Score of nuclear } \\
\text { pleomorphism }\end{array}$ & $\begin{array}{l}\text { Sum of } \\
\text { scores }\end{array}$ & $\begin{array}{l}\text { Tumor } \\
\text { grade }\end{array}$ \\
\hline Tubular carcinoma & $2 / 10$ & 1 & 2 & 2 & 5 & I \\
\hline $\begin{array}{l}\text { Micropapillary } \\
\text { carcinoma }\end{array}$ & $1 / 10$ & 2 & 3 & 2 & 7 & II \\
\hline Ductal carcinoma & $1 / 10$ & 2 & 2 & 2 & 6 & II \\
\hline $\begin{array}{l}\text { Carcinoma-mixed } \\
\text { type }\end{array}$ & $2 / 10$ & 2 & 1 & 2 & 5 & I \\
\hline \multirow{2}{*}{$\begin{array}{l}\text { Carcinoma-complex } \\
\text { type }\end{array}$} & \multirow[t]{2}{*}{$2 / 10$} & 3 & 3 & 3 & 9 & III \\
\hline & & 2 & 3 & 3 & 8 & III \\
\hline $\begin{array}{l}\text { Fibromyxoid } \\
\text { sarcoma }\end{array}$ & $1 / 10$ & - & 1 & 3 & 4 & I \\
\hline $\begin{array}{l}\text { Undifferentiated } \\
\text { Sarcoma }\end{array}$ & $1 / 10$ & 3 & 3 & 3 & 6 & ॥ \\
\hline
\end{tabular}

Ductal carcinoma was also diagnosed in cases that showed neoplastic cells arranged in cords and tubules that surrounded slit-like lumina that were often lined by a double layer of epithelial cells exhibiting significant anisokaryosis and anisocytosis. Focal or multifocal areas of squamous differentiation and keratinization were present, with intracytoplasmic keratohyalin granules within some cells (Fig. $5 \mathrm{~b}$ ).

In mammary micropapillary carcinoma, neoplastic cells formed a morula-like micropapillary projecting in the mammary lumina. Cells showed pleomorphism, karyomegaly, and mitosis. An extensive necrosed area was seen in the neoplastic tissue, and leukocytic infiltration was observed in the interstitial tissue of the mammary gland. Interstitial and peripheral fibrosis was also observed (Fig. 5c).

Complex carcinoma was diagnosed in two cases. Epithelial cells and spindle-shaped myoepithelial cells were observed as infiltrating cords. A layer of myoepithelial cells combined with a small grouping of epithelial cells invaded the adjacent stroma (Fig. $5 \mathrm{~d}$ ). Mixed-type carcinoma was reported in one case (Fig. 5e), and showed irregular tubules lined by a single layer of epithelial cells with a scant cytoplasm, fusiform, or stellate myoepithelial cells combined with an abundant fibrous connective tissue and cartilage formation. The cartilage appeared as plaques of different sizes of low-to-moderate numbers of chondrocytes and chondroblasts. Mixed-type carcinoma was also diagnosed in two cases. In situ and infiltrative carcinomatous proliferation was seen in the focal areas of the mixed-type tumors. Epithelial cells were strongly positive for pan-cytokeratin, and myoepithelial cells were positive for P63, but not a-SMA. The connective tissue stroma was positive for vimentin (Fig. 6).

Malignant mesenchymal mammary gland sarcoma was recorded in two cases. Low-grade fibromyxoid sarcoma had fibroblastic spindleshaped cells arranged in a whirling growth pattern with myxoid and fibrous stroma. The fibrous areas showed varying degrees of cellularity, including some hypocellular areas formed entirely of dense collagenous tissue. Nuclear pleomorphism was seen and mitotic figures were rare. Prominent capillaries were observed. The tumor was surrounded by a fibrous capsule that infiltrated the adjacent tissues (Fig. $5 f$ ). The other sarcoma was composed of polygonal neoplastic cells arranged in solid cellular areas and clusters separated by a fine fibrovascular stroma. The neoplastic cells were undifferentiated with vesicular nuclei and showed frequent mitosis. They were moderately positive for vimentin and entirely negative for cytokeratin, a-SMA, and P63 (Fig. 6).

\section{Discussion}

The present study investigated the expression of miR-21, alterations in CA $15-3$, and CEA as serum mammary tumor markers and utilization of immunohistochemistry in the diagnosis of CMT. Elevated levels of thrombocytes, although within the normal reference range, was the most common abnormality recorded via hematology. 
CMT is frequently diagnosed, especially in female dogs [19]. In the present study, intact female dogs, with a median age of 9 years, were affected. Hormonal factors such as estrogen could be implicated [20]. The onset of CMT is believed to be influenced by age, hormones, and genetic predisposition and is rarely seen in young dogs (<3 years of age) [21].

The hormonal effect was also studied in human breast cancer pathology [22]. An incidence rate of $73 \%$ was previously reported in intact female dogs with an approximate age range of 8-13 years [23], and another study reported a mean age of 9.5 years [24]. In the present study, the German Shepherd was the most affected breed. Cocker Spaniels and German Shepherds were postulated to be at higher risk compared with other breeds [25]; however, Labrador Retrievers and Poodles were overrepresented in another study [20].

CMT diagnosis is relatively feasible using clinical data, which is collected and analyzed, and a combination of visual and palpation provides the practitioner with the necessary information to narrow differential diagnosis lists [26]. In the present study, two females showed multiple masses, and tumor size was taken as the size of the largest tumor, as described previously [27]. Radiological examination was conducted to confirm the absence of distant metastasis. It is recommended to conduct the left and right lateral view and ventrodorsal view to confirm or rule out the presence of metastasis [26].

Histological examination showed malignant mammary gland tumors that were either carcinoma or sarcoma. The most frequently recorded CMT was mixed-type, which is in line with the findings from previous studies [28, 29]. Tumor type according to histological classification may be correlated with grade and prognosis [30]. Further immunohistochemical studies are useful to identify the origin of neoplastic cells [31]. Keratin immunoreactivity was limited to epithelial cells. Myofibroblasts express both a-actin and vimentin, whereas connective tissue cells express vimentin. Myoepithelial cells are a major component of carcinomas, which usually express CK14, CK5, SMA, calponin, and p63 [32]. However, proliferating myoepithelial cells show a decreased expression of these markers with an increased expression of vimentin, and eventually become a fibroblast-like cell expressing only vimentin [10]. Identification of the type of neoplastic cells involved in the tumor was suggested to be important for tumor prognosis. Tumors with or without myoepithelial cells should be identified since it was proposed that myoepithelial cells presence in malignant tumors exhibit an inhibitory effect on neoplastic cells with subsequent favorable prognosis [28, 33]. In the present study, it was difficult to diagnose myoepithelial cells using hematoxylin and eosin-stained tissue sections; therefore, they were identified by P63 immunoreactivity but were negative for SMA. P63 is more specific for myoepithelial cells and shows no crossreactivity with stromal myofibroblasts compared with SMA and calponin [10].

Hematological alterations showed no significant reduction in erythrogram and $\mathrm{MCV}$, and $\mathrm{MCHC}$ were within the normal range. PCV and $\mathrm{Hb}$ were reported to be reduced, along with nearly normal values for other hematological parameters in CMTs [7, 34, 35]. Thrombocytes were elevated, but were within the normal reference range. Thrombocytosis and leukopenia were previously reported to be the most prominent change in malignant mammary tumors [36]. However, leukocytosis and anemia were associated with chronicity and extent of advanced stage [37]. Thrombocyte elevation was associated with a systematic inflammatory response [38]. Immune-mediated involvements and nontreated solid neoplasm were postulated as a cause [36].

The present study showed that CA 15 - 3 levels were elevated in association with CMT. Elevation of CA $15-3$ is correlated with disease stage, neoplastic cells activities, and its associated products [2,12]. The most widely used serum markers in breast cancer are CA $15-3$ and CEA. They are relatively inexpensive and require a less invasive method of sample collection compared with immunohistochemical tests, which have been used in veterinary medicine [12]. In human medicine, CA $15-3$ is considered a specific diagnostic and monitoring tool for mammary tumors [39]. It is mainly a monitoring tool for women breast cancer [40,41], and is elevated in around 70\% of advanced cases. Benign breast tumors also show elevated CA15-3 levels [42]. Higher levels of CA $15-3$ are positively correlated with tumor stage; for instance, stage III is associated with higher serum concentration compared with stage I, and this high concentration may be associated with poor outcomes [2, 43]. The present study did not detect changes in CEA between the control and disease groups, in line with a previous study [12]. However, other studies showed that a change is expected [27, 44]. Liver metabolism, kidney clearance rate, and method of assay could be implicated $[12,45]$. Moreover, the lower positivity rate of CEA compared with CA $15-3$ in breast cancer makes it a controversial marker for the diagnosis of this type of tumor [46]. Previous studies $[47,48]$ reported that CEA lacks predictive ability in metastatic breast cancer, although other studies correlated it with poor prognosis $[49,50]$. Furthermore, a strong relationship between elevated serum CA $15-3$ and advanced CMT has been observed, indicating CA $15-3$ has better diagnostic value than CEA [12].

The present study found that miRNA-21 expression was upregulated 12.84-fold in female dogs with CMT, which is in agreement with the findings of a previous study [51] that reported increased miRNA-21 expression in mammary gland neoplasms and a fivefold increase in carcinoma samples. Furthermore, miR-21 was significantly upregulated in CMTs [52]. The use of microRNAs as indicators is becoming more common in human medicine as they are stable, noninvasive, easy to assess markers [53]. miR-21, miR-155, and miR-10b are established as oncogenic and metastasis-promoting miRNAs in breast cancer [54, 55]. The oncogenes, miR-21 and miR-29b, are associated with several cancers, including human mammary cancer, and have consistently found to be upregulated in mammary cancers using microarray analysis

Page 6/18 
[56-59]. Moreover, miR-21 showed an increase in copy number in human mammary tumor tissues [60]. miR-21 targets both PTEN and TPM1, and loss of this miRNA results in increased caspase activity and subsequent apoptosis [59, 61]. Comparisons between normal mammary gland and neoplastic tissues showed that miR-21, miR-143, miR-194, and miR-203 were significantly increased and therefore matched the definition of an oncogenic miRNA [62]. miR-21 is a substantial biomarker for the diagnosis of breast cancer in human patients [63]. Despite the broad use of miR-21and its misregulation in association with different carcinomas, it remains a promising marker for the prognosis, diagnosis, and prediction of cancer [53].

The tumors presented in the present study showed positive vimentin immunoreactivity, either partially or completely, with high expression of miR-21, indicating a mesenchymal origin of the tumor cells. Similarly, in a previous study on esophageal squamous cell carcinoma, miR-21 expression was predominantly present in fibroblasts associated with cancer [64]. Therefore, elevation of miR-21 may be directly attributed to mesenchymal cells expressing vimentin.

Limitations of this study, small number enrolled while strains of this study comparison between miR-21 and serum tumor marker. The attribution between high expression of miR-21 and mesenchymal origin of tumor cell required further investigation.

\section{Conclusions}

The present study showed that serum miR-21 was elevated 12.84-fold, which was greater than the threefold increase in CA15-3. Mixed-type tumors with positive vimentin immunoreactivity showed the highest levels of miR-21, confirming that miR-21 is mainly released from mesenchymal cells. These findings support the notion that miR-21 may be a more sensitive, noninvasive indicator of CMT.

\section{Methods}

\section{Animals, examination, and allocation}

The study included 17 non-lactating and non-pregnant female dogs admitted to the Veterinary Teaching Hospital, Faculty of Veterinary Medicine, Cairo University. Ten dogs had mammary tumors and seven healthy dogs were used as a control group and underwent a complete examination to exclude any underlying diseases (Table 1).

Physical examination of mammary glands was performed via inspection and palpation for masses on all five pairs of glands. Clinical signs were recorded at the time of admission. The control group comprised healthy dogs $\left(T_{0}\right)$ free from mammary tumors or any health issue, whereas the disease group comprised dogs with mammary tumor $\geq 3 \mathrm{~cm}$ in diameter and no evidence of metastasis $\left(T_{2,3}, N_{0}-1, M_{0}\right)$, as adapted from the World Health Organization guidelines [26, 27, 65]. In cases with more than one mass, the largest was used for tumor size [27].

\section{Radiographical Examination}

Radiographical recordings made using X-ray (Fischer, Berlin, Germany). The radiographical setting factors were 58-70 kVp, 10 mAs, and 90$\mathrm{cm}$ focal spot-film distance. The radiographical exposures were conducted dorsoventrally and right laterally. The tumor dimensions were measured using calipers and confirmed with sonar.

\section{Routine Hematology}

Blood was collected from the cephalic vein of each dog and then divided into two portions. The first portion was collected in an EDTAcontaining tube for hematology analysis by an automated veterinary hematology analyzer. The second portion was collected in a sterile tube for serum separation.

\section{Serum Tumor Markers}

Blood was collected from the animals in both groups into a sterile tube for serum separation and divided into two aliquots. The first aliquot was used to determine CEA and CA $15-3$ levels (MyBiosource, USA). The second aliquot was stored immediately at $-20^{\circ} \mathrm{C}$ until used to measure miR-21 expression. 


\section{Determination Of Serum Mir-21}

RNA was extracted from serum samples using a RNeasy Mini kit (catalog no.74104, QIAGEN, Germany) according to manufacturer's instructions. Quantitative PCR was performed using a QuantiTect SYBR green PCR kit (Cat. No.204141, QIAGEN, Germany). The primers used in SYBR green real-time PCR for miR-21 and U6 (housekeeping gene) are shown in Table 6 [66, 67]. The cycling conditions for SYBR green real-time PCR are illustrated in Table 7. Amplification curves and cycle threshold $\left(\mathrm{C}_{\mathrm{T}}\right)$ values were determined using Stratagene MX3005P software. The $\mathrm{C}_{\mathrm{T}}$ value of each sample was compared with that of the control group according to the " $\Delta \Delta \mathrm{C}_{\mathrm{T}}$ " method [68] using following ratio $2^{-\triangle \triangle C T}$ to estimate the variation in gene expression in the different samples.

Table 6

Primers sequence for MiR-21 and housekeeping gene (U6)

\begin{tabular}{|ll|}
\hline Gene & $\begin{array}{l}\text { Primer sequence } \\
\left(\mathbf{5}^{\prime}-\mathbf{3}^{\prime} \mathbf{)}\right.\end{array}$ \\
\hline $\begin{array}{l}\text { U6 } \\
\text { (housekeeping) }\end{array}$ & $\begin{array}{l}\text { GCTTCGGCAGCACATATACTAAAAT } \\
\text { CGCTTCACGAATTTGCGTGTCAT }\end{array}$ \\
\hline miRNA-21 & CGGCGGTAGCTTATCAGACTGATGT \\
& GTGCAGGGTCCGAGGT \\
\hline
\end{tabular}

Table 7

Cycling condition of real-time PCR for MiR-21 and housekeeping gene (U6)

\begin{tabular}{|c|c|c|c|c|c|c|c|c|}
\hline \multirow[t]{2}{*}{ Gene } & \multirow[t]{2}{*}{$\begin{array}{l}\text { Reverse } \\
\text { transcription }\end{array}$} & \multirow[t]{2}{*}{$\begin{array}{l}\text { Primary } \\
\text { denaturation }\end{array}$} & \multicolumn{3}{|c|}{ Amplification (40 cycles) } & \multicolumn{3}{|c|}{$\begin{array}{l}\text { Dissociation curve } \\
\text { (1 cycle) }\end{array}$} \\
\hline & & & $\begin{array}{l}\text { Secondary } \\
\text { denaturation }\end{array}$ & $\begin{array}{l}\text { Annealing } \\
\text { (Optics } \\
\text { on) }\end{array}$ & Extension & $\begin{array}{l}\text { Secondary } \\
\text { denaturation }\end{array}$ & Annealing & $\begin{array}{l}\text { Final } \\
\text { denaturation }\end{array}$ \\
\hline \multirow{2}{*}{$\begin{array}{l}\text { U6 } \\
\text { (housekeeping) }\end{array}$} & $50^{\circ} \mathrm{C}$ & $94^{\circ} \mathrm{C}$ & $94^{\circ} \mathrm{C}$ & $60^{\circ} \mathrm{C}$ & $72^{\circ} \mathrm{C}$ & $94^{\circ} \mathrm{C}$ & $60^{\circ} \mathrm{C}$ & $94^{\circ} \mathrm{C}$ \\
\hline & $30 \mathrm{~min}$. & 15 min. & $15 \mathrm{sec}$. & $30 \mathrm{sec}$. & $30 \mathrm{sec}$. & $1 \mathrm{~min}$. & $1 \mathrm{~min}$. & $1 \mathrm{~min}$. \\
\hline \multirow[t]{2}{*}{ miRNA-21 } & $50^{\circ} \mathrm{C}$ & $94^{\circ} \mathrm{C}$ & $94^{\circ} \mathrm{C}$ & $60^{\circ} \mathrm{C}$ & $72^{\circ} \mathrm{C}$ & $94^{\circ} \mathrm{C}$ & $60^{\circ} \mathrm{C}$ & $94^{\circ} \mathrm{C}$ \\
\hline & $30 \mathrm{~min}$. & $15 \mathrm{~min}$. & $15 \mathrm{sec}$. & $30 \mathrm{sec}$. & $30 \mathrm{sec}$. & $1 \mathrm{~min}$. & $1 \mathrm{~min}$. & $1 \mathrm{~min}$. \\
\hline
\end{tabular}

\section{Surgical Intervention}

\section{Surgical intervention}

General anesthesia was applied to animals during the surgical mastectomy (Fig. 7). Under general injectable anesthesia, each animal was premedicated with atropine sulfate (1\%, 0.05-0.1 mg/kg b. wt.; Adwia Co. S.A.E., Cairo, Egypt) and xylazine (Xyla-Ject $2 \%, 1$ mg/kg b. wt.; Adwia Co. S.A.E.), and then anesthesia was induced using ketamine $\mathrm{HCl}$ (Ketalar, 10-15 mg/kg b. wt.; Sigma-Aldrich Co.) and maintained by ketamine $\mathrm{HCl}$ [69]. After complete recovery the animals were discharged to owner care, during postoperative care the animal was medicated using cefobid $\AA 500 \mathrm{mg}$ IMM twice daily, fluid therapy for 3 days, daily dressing on wound with normal saline, fucidine $\AA$ cream and bevatracin $\circledast$ spray, follow up after 10-14 days was performed to remove stitch.

\section{Histopathology, Histological Grading, And Immunohistochemistry Of Mammary Tissue}

Mammary tissue specimens were fixed in 10\% neutral buffered formalin, processed by paraffin-embedded technique, and sectioned into 34- $\mu$ m thick sections using a microtome (Leica 2135, Germany). Tissue sections were stained with hematoxylin and eosin for histopathological examination using a light microscope equipped with a digital camera (Olympus XC30, Tokyo, Japan). Canine tumors were diagnosed according to a proposed histological classification previously [8].

The tumors were graded according to the Elston and Ellis scoring system [70], in which three morphological features were assessed: glandular differentiation and tubule formation, nuclear pleomorphism, and mitotic activity. A score of 1-3 was used to evaluate each 
parameter [71]. Tubule formation with clear central lumina was scored 1 when comprising $>75 \%$ of the tumor, 2 when comprising $10-75 \%$ of the tumor, and 3 when comprising $<10 \%$ of the tumor. The nuclear pleomorphism was scored 1 when small uniform regular cells were present, 2 when nuclear size and variation was moderate, and 3 when the nuclear variation was marked. The number of cells undergoing mitosis per 10 high-power fields ( $40 \times$ ) was scored as: 1 ( $0-7$ mitosis), 2 ( $8-16$ mitosis), and 3 ( $\geq 17$ mitoses). The sum of the three scores was used to grade each tumor as follows: grade I, well-differentiated, or low-grade (3-5 points); grade II, moderately differentiated or intermediate-grade (6-7 points); and grade III, poorly differentiated or high-grade (8-9 points).

Cytokeratin, vimentin, a-SMA, and P63 were immunohistochemically stained in paraffin-embedded tissue sections after deparaffinization and hydration of the tissue to differentiate between different types of undiagnosed tumors. Anti-pan-cytokeratin (PCK) (rabbit polyclonal, 1:100, Dako), anti-vimentin (mouse monoclonal, 1:100, Dako), anti-a-SMA (mouse monoclonal, 1:100, Dako), anti-p63 (mouse monoclonal, 1:50, Dako, Carpinteria, USA) were applied to tissue sections after antigen retrieval by citrate buffer ( $\mathrm{pH} 6$ ) and blocking of endogenous peroxidase activity with $3 \% \mathrm{H}_{2} \mathrm{O}_{2}$. A secondary horseradish peroxidase-conjugated anti-species antibody (Envision, Dako, Carpinteria, USA) was then applied for one-hour. 3 3'-diaminobenzidine (Dako, Carpinteria, USA) was used to develop a brown color.

\section{Statistical analysis}

Age was presented as median values. All quantitative data of hematology and serum tumor markers (CEA, CA $15-3)$ were presented as mean \pm standard error. Comparison between the control and disease groups were performed using SPSS statistics program version 16.0 (independent samples T-test).

\section{Abbreviations}

CA $15-3$, cancer antigen $15-3$; CEA, carcinoembryonic antigen; CMT, canine mammary tumor; miR-21, microRNA-21; MT, mammary tumor.

\section{Declarations}

\section{Ethical approval and consent to participate}

This study was granted an ethical approval permission of the Institutional Animal Care and Use Committee, Cairo University (Vet CU 20022020127). The animals enrolled in this study were privately- owned animals, for that, verbal owners' consent was obtained from all participants.

\section{Consent for publications}

Not applicable

\section{Availability of data and materials}

All the relevant data for this manuscript are presented in the manuscript.

\section{Competing interests}

The authors declare that they have no competing interests.

\section{Funding}

This study did not receive grants or funds.

\section{Author contributions}

All authors designed the study. NYS and ESR performed clinical examination and estimated serum tumor markers and miR-21 expression. NAA, IAE, and HAF performed diagnostic imaging and surgical interference. MSK performed pathological examination. All authors wrote the paper, read and approved the final manuscript.

\section{Acknowledgments}


The authors thank the small animals' teaching hospital, faculty of veterinary medicine for facilitating this work. Authors thank Enago ${ }^{\text {Tm }}$ for professional English language review.

\section{References}

1. Bonnett BN, Egenvall A, Hedhammar A, Olson P. Mortality in over 350,000 insured Swedish dogs from 1995-2000: I. Breed-, gender-, age- and cause-specific rates. Acta Vet Scand. 2005;46(3):105-20.

2. Manuali E, De Giuseppe A, Feliziani F, Forti K, Casciari C, Marchesi MC, Pacifico E, Pawłowski KM, Majchrzak K, Król M. CA 15 - 3 cell lines and tissue expression in canine mammary cancer and the correlation between serum levels and tumour histological grade. BMC vet res. 2012;8:86.

3. Banerjee A, Islam MM, Das M, Chakrabarty S, Chowdhury S, Sarkar S. Hemato-Biochemical Alterations Associated with Malignant Mammary Tumours in Canine. Environment Ecology. 2018;36(3):860-3.

4. Simeonov R, Stoikov D. Study on the correlation between the cytological and histological tests in the diagnostics of canine spontaneous mammary neoplasms. Bulg J vet med. 2006;9(3):211-9.

5. Henry CJ, Higginbotham ML. Cancer management in small animal practice. 1st ed. Saunders; 2010.

6. Moris J, Dobson J. Text-book of small animal oncology. Blackwell Science; 2001.

7. Kumar VVVA, Kumari KN, Kumar KS, Kumar VG, Lakshman M. Hemato-biochemical changes in mammary tumors affected dogs. J Pharm Innov. 2018;7(2):187-9.

8. Goldschmidt M, Peña L, Rasotto R, Zappulli V. Classification and grading of canine mammary tumors. Vet Pathol. 2011;48(1):117-31.

9. Chocteau F, Abadie J, Loussouarn D, Nguyen F. Proposal for a Histological Staging System of Mammary Carcinomas in Dogs and Cats. Part 1: Canine Mammary Carcinomas. Front Vet Sci. 2019;6:388.

10. Sorenmo KU, Rasotto R, Zappulli V, Goldschmidt MH. Development, Anatomy, Histology, Lymphatic Drainage, Clinical Features, and Cell Differentiation Markers of Canine Mammary Gland Neoplasms. Vet Pathol. 2011;48(1):85-97.

11. Eisenberg ALA, Koifman S. Breast cancer: Tumor markers. Rev Bras Canc. 2001;47:377-88.

12. Campos LC, Lavalle GE, Estrela-Lima A, Melgac JC, de Faria O, Guimara JE, Dutra AP, Ferreira E, de Sousa LP, Rabelo EML, Vieira da Costa AFD, Cassali GD. CA15.3, CEA and LDH in dogs with malignant mammary tumors. J Vet Intern Med. 2012; 26(6):1383-1388.

13. Lu J, Getz G, Miska EA, Alvarez-Saavedra E, Lamb J, Peck D, Sweet-Cordero A, Ebert BL, Mak RH, Ferrando AA, Downing JR, Jacks T, Robert Horvitz H, Golub TR. MicroRNA expression profiles classify human cancersNature. 2005;435:834-8.

14. Eman SR, Kubesy AA, Baraka TA, Torad FA, Shaymaa IS, Mohammed FF. Evaluation of hepatocyte-derived microRNA-122 for diagnosis of acute and chronic hepatitis of dogs. Vet World. 2018;11(5):667-73.

15. Ramadan ES, Kubesy AA, Baraka TA, Torad FA, Shaymaa IS, Salem NY. Expression of blood hepatocyte-derived microRNA-122 in canine multicentric lymphoma with hepatic involvement. Vet Res Commun. 2019;43:231-8.

16. Iorio MV, Ferracin M, Liu CG, Veronese A, Spizzo R, Sabbioni S, Magri E, Pedriali M, Fabbri M, Campiglio M, Me'nard S, Palazzo JP, Rosenberg A, Musiani P, Volinia S, Nenci I, Calin GA, Querzoli P, Negrini M. Croce CM.MicroRNA gene expression deregulation in human breast cancer. Cancer Res. 2005;65(16):7065-70.

17. Boggs RM, Wright ZM, Stickney MJ, Porter WW. Murphy KE.MicroRNA expression in canine mammary cancer. Mamm Genome. 2008;19(7-8):561-9.

18. Hong L, Yang J, Han Y, Lu Q, Cao J, Syed L. High expression of miR-210 predicts poor survival in patients with breast cancer: a metaanalysis.Gene.2012;507(2):135-138.

19. Benavente MA, Bianchi CP, Aba MA. Canine mammary tumors: risk factors, prognosis and treatments.J Vet Adv. 2016; 6:1291-300.

20. Salas Y, Márquez A, Diaz D, Romero L. Epidemiological study of mammary tumors in female dogs diagnosed during the period 20022012: A growing animal health problem. PLoS One. 2015;10(5):e0127381.

21. Egenvall $A$, Bonnett BN, Ohagen $P$, Olson $P$, Hedhammar A, von Euler H. Incidence of and survival after mammary tumors in a population of over 80,000 insured female dogs in Sweden from1995 to 2002. Prev Vet Med. 2005;69(1-2):109-27.

22. Cotran R, Kumar V, Robbins SL, et al. Pathologic Basis of Disease. Philadelphia: W.B. Saunders; 1994.

23. Vascellari M, Capello K, Carminato A, Zanardello C, Baioni E, Mutinelli F. Incidence of mammary tumors in the canine population living in the Veneto region (Northeastern Italy): Risk factors and similarities to human breast cancer. Prev Vet Med. 2016;126:183-9.

24. Sorenmo KU, Kristiansen VM, Cofone MA, Shofer FS, Breen AM, Langeland M, Mongil CM, Grondah AM, Teige J. Goldschmidt MH.Canine mammary gland tumours; a histological continuum from benign to malignant; clinical and histopathological evidence. Vet Comp Oncol. 2009;7:162-72. 
25. Sleeckx N, de Rooster H, Veldhuis Kroeze E, Van Ginneken C, Van Brantegem L. Canine Mammary Tumours, an Overview. Reprod Domest Anim. 2011;46:1112-31.

26. Rivera P. Biochemical markers and genetic risk factors in canine tumors. Doctoral thesis, Swedish university of agricultural sciences. 2010 .

27. Senhorello ILS, Terra EM, Sueiro FAR, Firmo BF, Anai LA, Goloni C, Canavari IC, Ampuero RAN, Pereira RS, Tinucci-Costa M. Clinical value of carcinoembryonic antigen in mammary neoplasms of bitches. Vet Comp Oncol. 2020;18:315-23.

28. Misdorp W, Else RW, Hellmen E. Histological classification of mammary tumors of the dog and the cat. Geneva: World Health Organization; 1999.

29. Cassali GD, Lavalle GE, De Nardi AB, Ferreira E, Bertagnolli AC, Estrela-Lima A, Alessi AC, Daleck CR. Consensus for the diagnosis, prognosis and treatment of canine mammary tumors. Braz J Vet Pathol. 2011;4(2):153-80.

30. Karayannopoulou M, Kaldrymidou E, Constantinidis TC, Dessiris A. Histological grading and prognosis in dogs with mammary carcinomas: application of a human grading method. J Comp Pathol. 2005;133:246-52.

31. Dolka I, Sapierzyński R, Król M. Retrospective study and immunohistochemical analysis of canine mammary sarcomas. BMC Vet Res. 2013;9:248.

32. Destexhe E, Lespagnard L, Degeyter M, Eymann RH, Coignoul F. Immunohistochemical identification of myoepithelial, epithelial, and connective tissue cells in canine mammary tumors. Vet Pathol. 1993;30(2):146-54.

33. Pandey PR, Saidou J, Watabe K. Role of myoepithelial cells in breast tumor progression. Front Biosci. 2010;15:226-36.

34. Pankaj G, Raghunath M, Gupta AK, Ankur S, Kawardeep K. Clinical study for diagnosis and treatment of canine mammary Neoplasms (CMNs) using different modalities. Indian J Anim Res. 2014;48(1):45-9.

35. Mohapatra AK, Das D, Panda SK, Singh J. Spontaneous canine mammary neoplasia: A clinico pathological study. Cell Tissue Res. 2016;16(2):5661-6.

36. Lallo MA, Ferrarias TM, Adriane Stravino, Rodriguez JFM, Zucare RLC. Hematologic abnormalities in dogs bearing mammary tumors. R bras Ci Vet. 2016;23(1-2):3-8.

37. Da Silva AHC, Da Silva DM, Ribas CR, Dittrich RL, Dornbusch PT, Guérios SD. Alterações no hemograma de cadelas com neoplasia mamária. Ciência Animal Brasileira. 2014;15:87-92. [Complete blood count changes in bitches with mammary tumor].

38. Alexandrakis MG, Passam FH, Perisinakis K, Ganotakis E, Margantinis G, Kyriakou DS, Bouros D. Serum pro-inflammatory cytokines and its relationship to clinical parameters in lung cancer patients with reactive thrombocytosis. Respir Med. 2002;96:553-8.

39. Marchesi MC, Manuali E, Pacifico E, Ferri C, Romagnoli M, Mangili V, Fruganti G. Cancer antigen 15/3: Possible diagnostic use in veterinary clinical oncology. Preliminary study. Vet Res Commun. 2010;34:103-6.

40. Duffy MJ, Shering S, Sherry F, McDermott E, O’Higgins N. CA 15 - 3: a prognostic marker in breast cancer. Int J Biol Markers. 2000;15(4):330-3.

41. Ebeling FG, Stieber P, Untch M, Nagel D, Konecny GE, Schmitt UM, Fateh-Moghadam, Seidel D. Serum CEA and CA 15 - 3 as prognostic factors in primary breast cancer. Br J Cancer. 2002;86(8):1217-22.

42. Marella S. Prognostic and predictive markers in early detection of different types of cancers for selected organ sites. IOSR J P B S. 2013;8(4):25-42.

43. Kaszak I, Ruszczak A, Kanafa S, Kacprzak K, Król M, Jurka P. Current biomarkers of canine mammary tumors. Acta vet Scand. 2018;60(1):66.

44. Balint E, Manolescu N, Braslasu D, et al. Molecular detection through CEA (carcino-embrionic-antigen) of different types of cancer in animal. Lucra` ri Stiintifice Medicina` Veterinara`. 2008;51:89-93.

45. Waisberg J, Landman G, Cha ASH, et al. Standard of the tecidual distribution of the CEA in the carcinoma col-retal: Relation with the serico level of the CEA and sorting of Dukes. Rev Bras Colo-proctol. 2002;22:20-6.

46. Li X, Dai D, Chen B, Tang H, Xie X, Wei W. Clinicopathological and prognostic significance of cancer antigen $15-3$ and carcinoembryonic antigen in breast cancer: A Meta-Analysis including 12,993 Patients. Dis markers. $2018 ; 9863092$.

47. Loprinzi CL, Tormey DC, Rasmussen P, Falkson G, Davis TE, Falkson HC, Chang AY. Prospective evaluation of carcinoembryonic antigen levels and alternating chemotherapeutic regimens in metastatic breast cancer. J Clin Oncol. 1986;4(1):46-56.

48. Nan J, Li J, Li X, Guo G, Wen X, Tian Y. Preoperative serum carcinoembryonic antigen as a marker for predicting the outcome of three cancers. Biomark Cancer.2017; 9.

49. Lee JS, Park S, Park JM, Cho JH, Kim SI, Park BW. Elevated levels of preoperative CA 15 - 3 and CEA serum levels have independently poor prognostic significance in breast cancer. Ann Oncol. 2013;24(5):1225-31.

Page $11 / 18$ 
50. Dai D, Chen B, Tang H, Wang IN, Zhao Z, Xie X, Wei W. Nomograms for predicting the prognostic value of pre-therapeutic CA15-3 and CEA serum levels in TNBC patients. PLoS One.2016; 11(8).

51. Łosiewicz K, Chmielewska-Krzesińska M, Socha P, Jakimiuk A, Wąsowicz K. MiRNA-21, miRNA-10b, and miRNA-34a expression in canine mammary gland neoplasms. Bull Vet Inst Pulawy. 2014;58:447-51.

52. Boggs RM, Wright ZM, Stickney MJ, Porter WW, Murphy KE. MicroRNA expression in canine mammary cancer. Mamm Genome. 2008;19:561-9.

53. Bautista-Sánchez D, Arriaga-Canon C, Pedroza-Torres A, De La Rosa-Velázquez I, González-Barrios R, Contreras-Espinosa L, MontielManríquez R, Castro-Hernández C, Fragoso-Ontiveros V, Álvarez-Gómez RM. Herrera LA. The Promising role of miR-21 as a cancer biomarker and its importance in RNA-based therapeutics. Mol Ther Nucleic acids. 2020;20:409-20.

54. Ma L, Teruya-Feldstein J, Weinberg RA. Tumour invasion and metastasis initiated by microRNA-10b in breast cancer. Nature. 2007;449:682-8.

55. Yan LX, Huang XF, Shao Q, Huang MY, Deng L, Wu QL, Zeng YX, Shao JY. MicroRNA miR-21 overexpression in human breast cancer is associated with advancer clinical stage, lymph node metastasis and patient poor prognosis. RNA. 2008;14:2348-60.

56. Blenkiron C, Goldstein LD, Thorne NP, Spiteri I, Feung Chin S, Dunning MJ, Barbosa-Morais NL, Teschendorff AE, Green AR, Ellis IO, Tavaré S, Caldas C, Miska EA. MicroRNA expression profiling of human breast cancer identifies new markers of tumour subtype. Genome Biol. 2007;8:R214.

57. Fabbri M, Garzon R, Cimmino A, Liu Z, Zanesi N, Callegari E, Liu S, Alder H, Costinean S, Fernandez-Cymering C, Volinia S, Guler G, Morrison CD, Chan KK, Marcucci G, Calin GA, Huebner K, Croce CM. MicroRNA-29 family reverts aberrant methylation in lung cancer by targeting DNA methyltransferases 3A and 3B. Proc Natl Acad Sci USA. 2007;104:15805-10.

58. Si ML, Zhu S, Wu H, Lu Z, Wu F, Mo YY. miR-21-mediated tumor growth.Oncogene. 2007; 26: 2799-2803.

59. Zhu S, Si ML, Wu H, Mo YY. MicroRNA-21 targets the tumor suppressor gene tropomyosin 1 (TPM1). J Biol Chem. 2007;282:14328-36.

60. Zhang L, Huang J, Yang N, Greshock J, Megraw MS, Giannakakis A, Liang S, Naylor TL, Barchetti A, Ward MR, Yao G, Medina A, Coukos G. microRNAs exhibit high frequency genomic alterations in human cancer. Proc Natl Acad Sci USA. 2006;103:9136-41.

61. Meng F, Henson R, Wehbe-Janek H, Ghoshal K, Jacob ST, Patel T. MicroRNA-21 regulates expression of the PTEN tumor suppressor gene in human hepatocellular cancer. Gastroenterology. 2007;133:647-58.

62. von Deetzen MC, Schmeck BT, Gruber AD, Klopfleisch R. Malignancy Associated MicroRNA expression changes in canine mammary cancer of different malignancies. research article, Hindawi Publishing Corporation ISRN Veterinary Science 2014.

63. Wang H, Tan Z, Hu H, Liu H, Wu T, Zheng C, Wang X, Luo Z, Wang J, Liu S, Lu Z, Tu J. microRNA-21 promotes breast cancer proliferation and metastasis by targeting LZTFL1. BMC Cancer. 2019;19(1):738.

64. Nouraee N, Van Roosbroeck K, Vasei M, Semnani S, Samaei NM, Naghshvar F, Omidi AA, Calin GA, Mowla SJ. Expression tissue distribution and function of miR-21 in esophageal squamous cell carcinoma. PLoS One. 2013;8(9):e73009.

65. Owen L. TNM Classification of Tumors in Domestic Animals. Geneva: World Health Organization; 1980.

66. Chen Y, Sun Y, Chen L, Xu X, Zhang X, Wang B, Min L, Liu W. miRNA-200c increases the sensitivity of breast cancer cells to doxorubicin through the suppression of E-cadherin-mediated PTEN/Akt signaling. Mol Med Rep. 2013;7(5):1579-84.

67. Wu Y, Song Y, Xiong Y, Wang X, Xu K, Han B, Bai Y, Li L, Zhang Y, Zhou L. MicroRNA-21 (Mir-21) promotes cell growth and invasion by repressing tumor suppressor PTEN in colorectal cancer. Cell Physiol Biochem. 2017;43(3):945-58.

68. Yuan JS, Reed A, Chen F, Stewart CN Jr. Statistical analysis of real-time PCR data. BMC Bioinf. 2006;7:85.

69. Abd Elkader NA, Emam IA, Farghali HA, Salem MDS. NY. Oesophageal foreign bodies in cats: Clinical and anatomic findings. PLoS One. 2020;15(6):e0233983. doi:10.1371/journal.pone.0233983. Published 2020 Jun 2.

70. Elston CW, Ellis IO. Assessment of histological grade. In: Elston CW, Ellis IO, editors. Systemic pathology - The breast. 3rd ed. London: Churchill \& Livingstone; 1998. pp. 365-84.

71. Tavasoly A, Golshahi H, Rezaie A, Farhadi M. Classification and grading of canine malignant mammary tumors. Vet Res Forum. 2013;4(1):25-30.

\section{Figures}




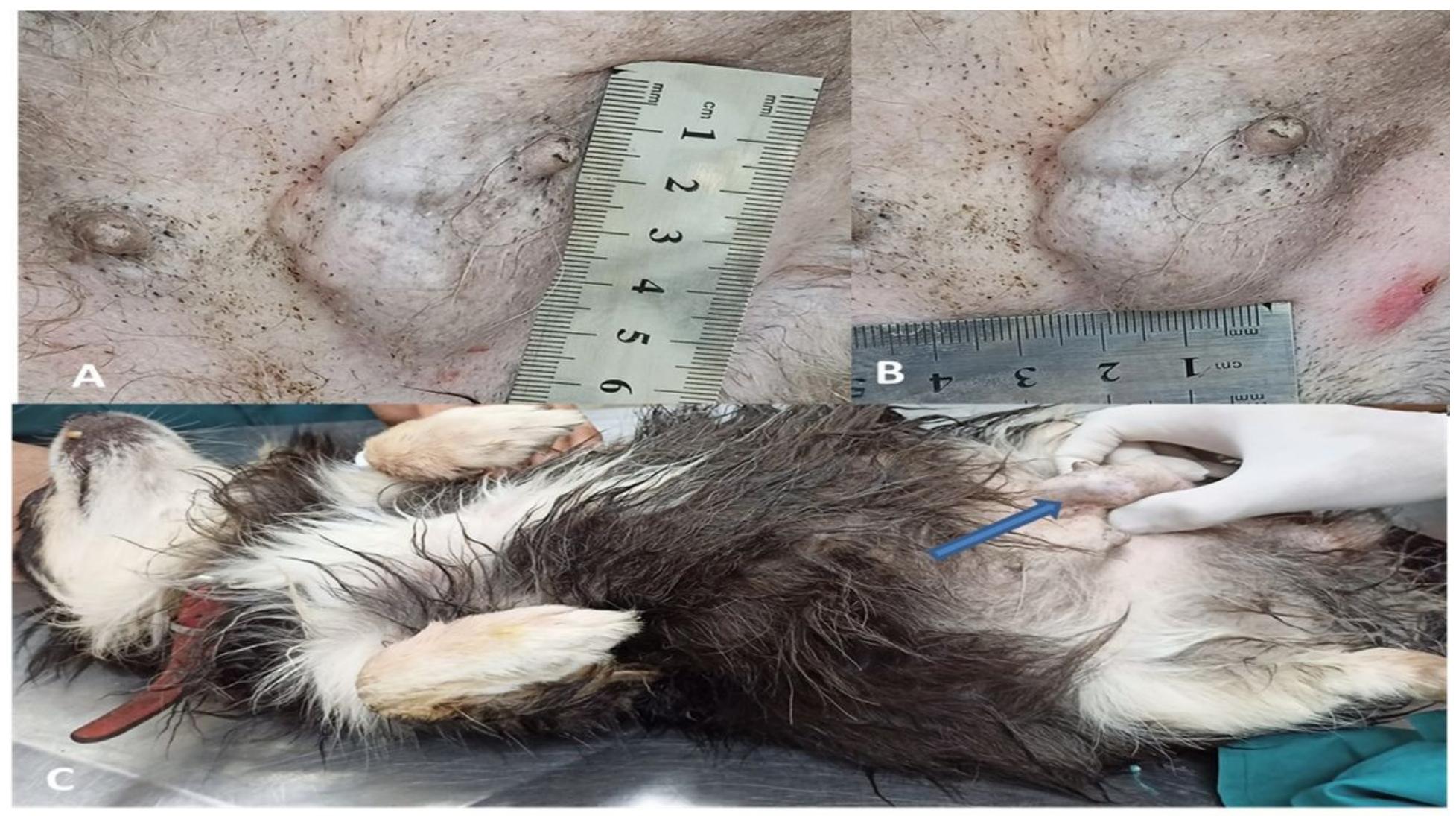

\section{Figure 1}

Photographs for North American shepherd dog 15 years; showing left inguinal tumor A, B: The tumor dimensions were measured using calipers. 


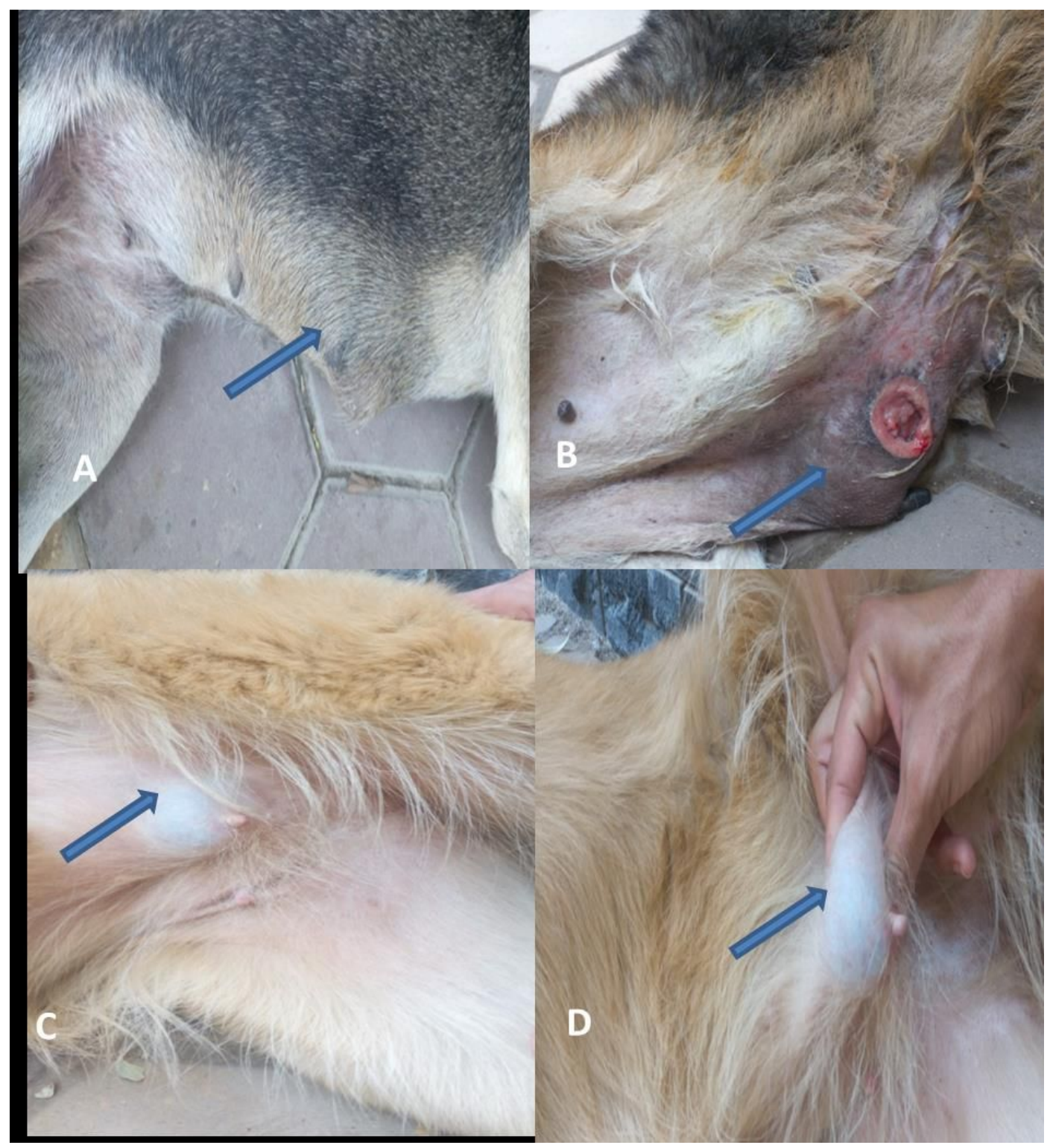

\section{Figure 2}

A Photographs for mongrel dog 7 years; showing right cranial abdomen tumor, B) German shepherd dog showing Left cranial abdomen +caudal abdominal tumor with ulceration, C, D) Photographs of Golden retriever dog showing left inguinal tumor. 

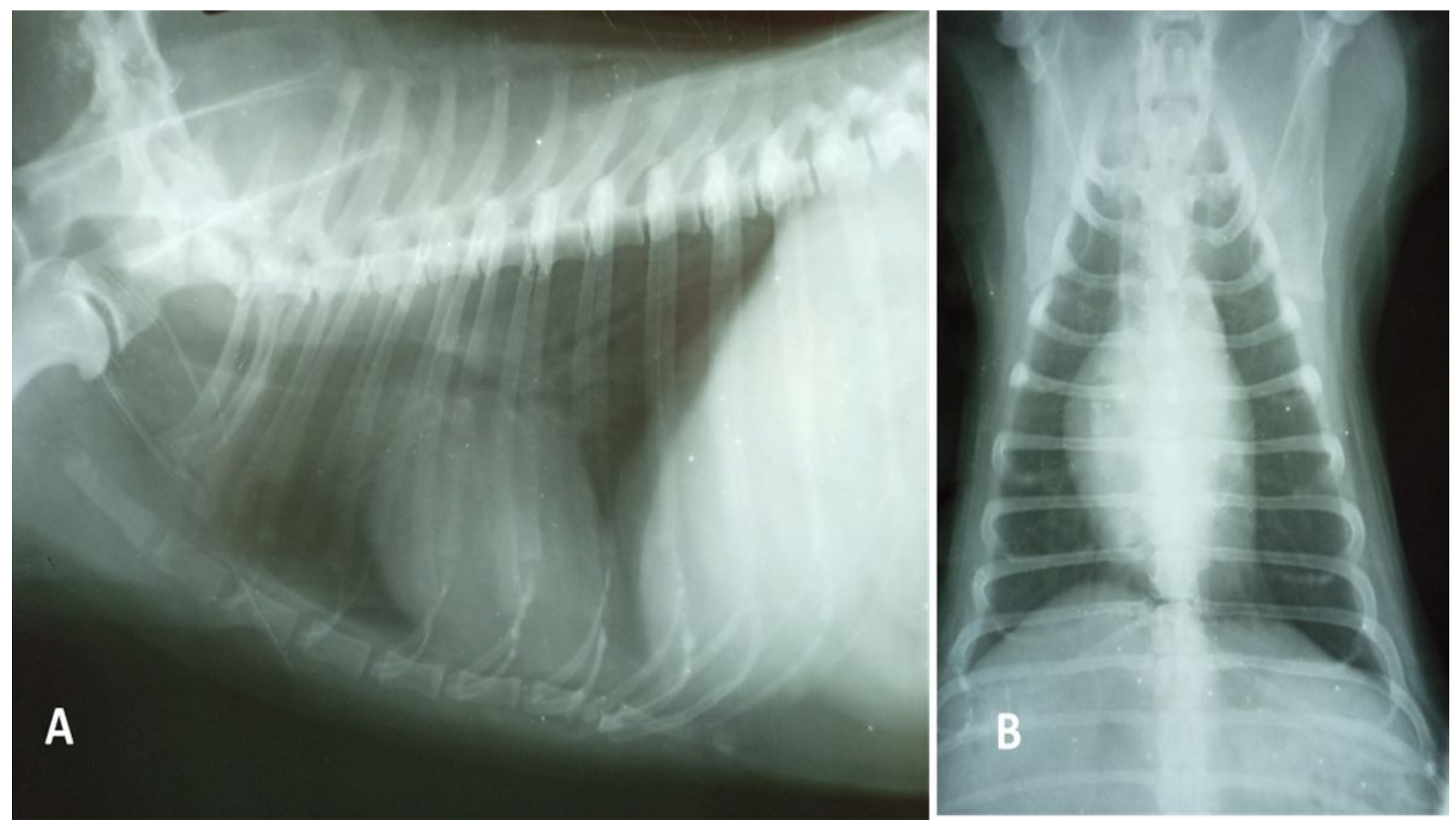

\section{Figure 3}

Right lateral (A) and ventrodorsal (B) radiographic views of the thorax of a female dog with a mammary tumor. No signs of metastases were observed in the lungs.

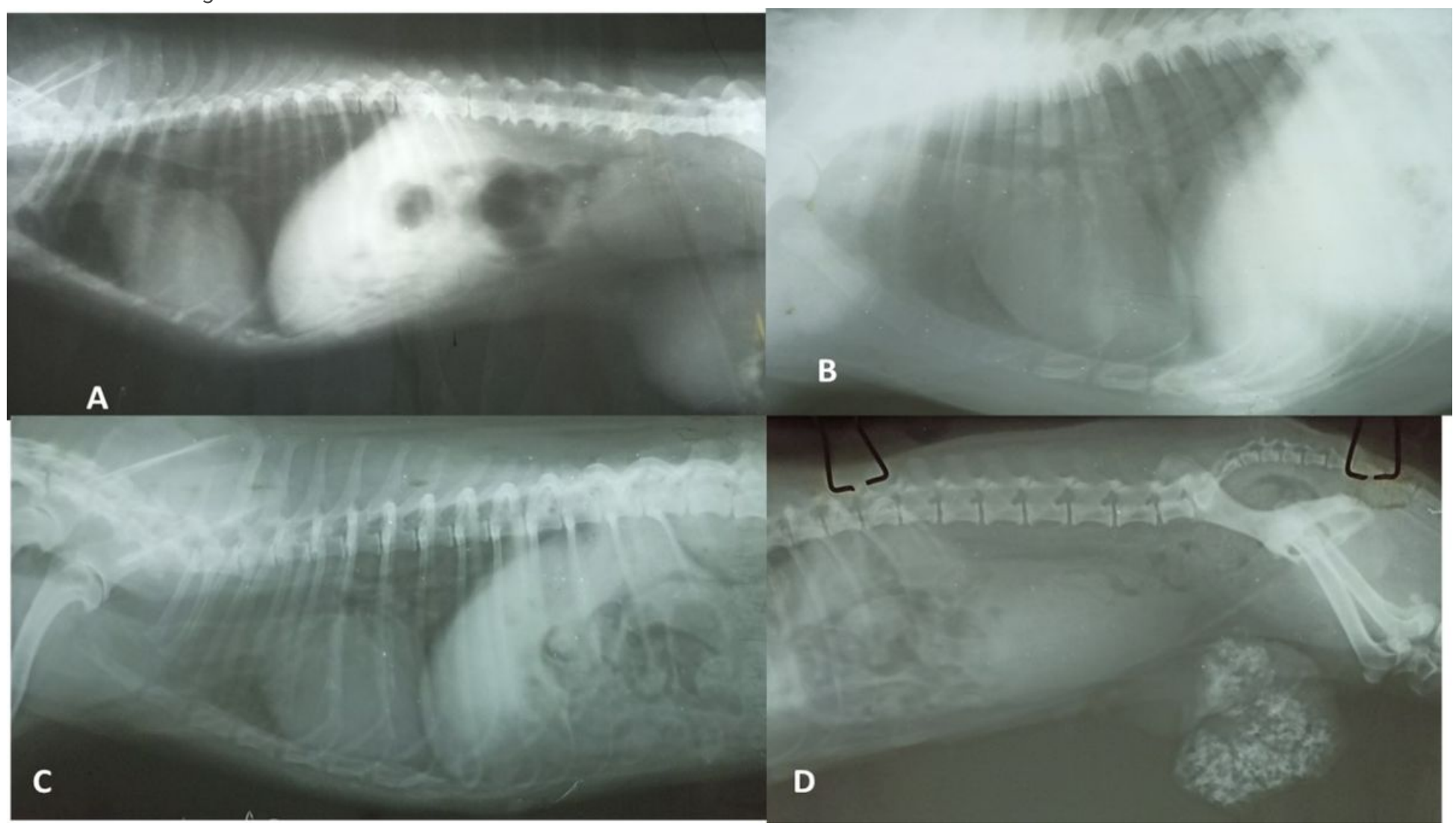

\section{Figure 4}


Right lateral radiographic views of the thorax of female dogs with a mammary tumor. No signs of metastases were observed in the lungs.

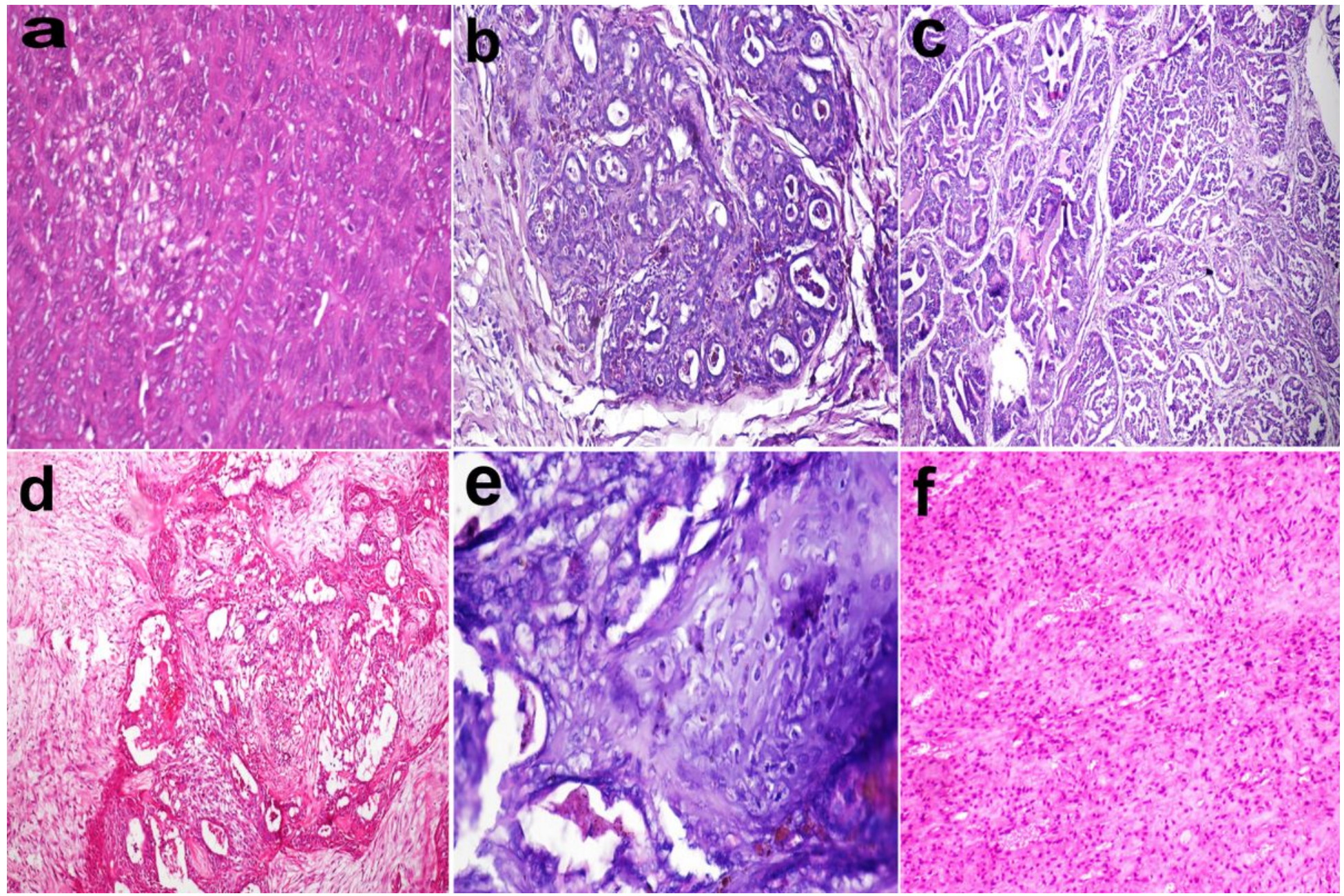

\section{Figure 5}

Canine mammary tumors. (a) Tubular adenocarcinoma (X40), (b) ductal carcinoma (X20), (c) micropapillary carcinoma, (d) complex carcinoma (X10), (e) mixed carcinoma (X40), and (f) fibromyxoid sarcoma (X20). Hematoxylin and eosin stain. 


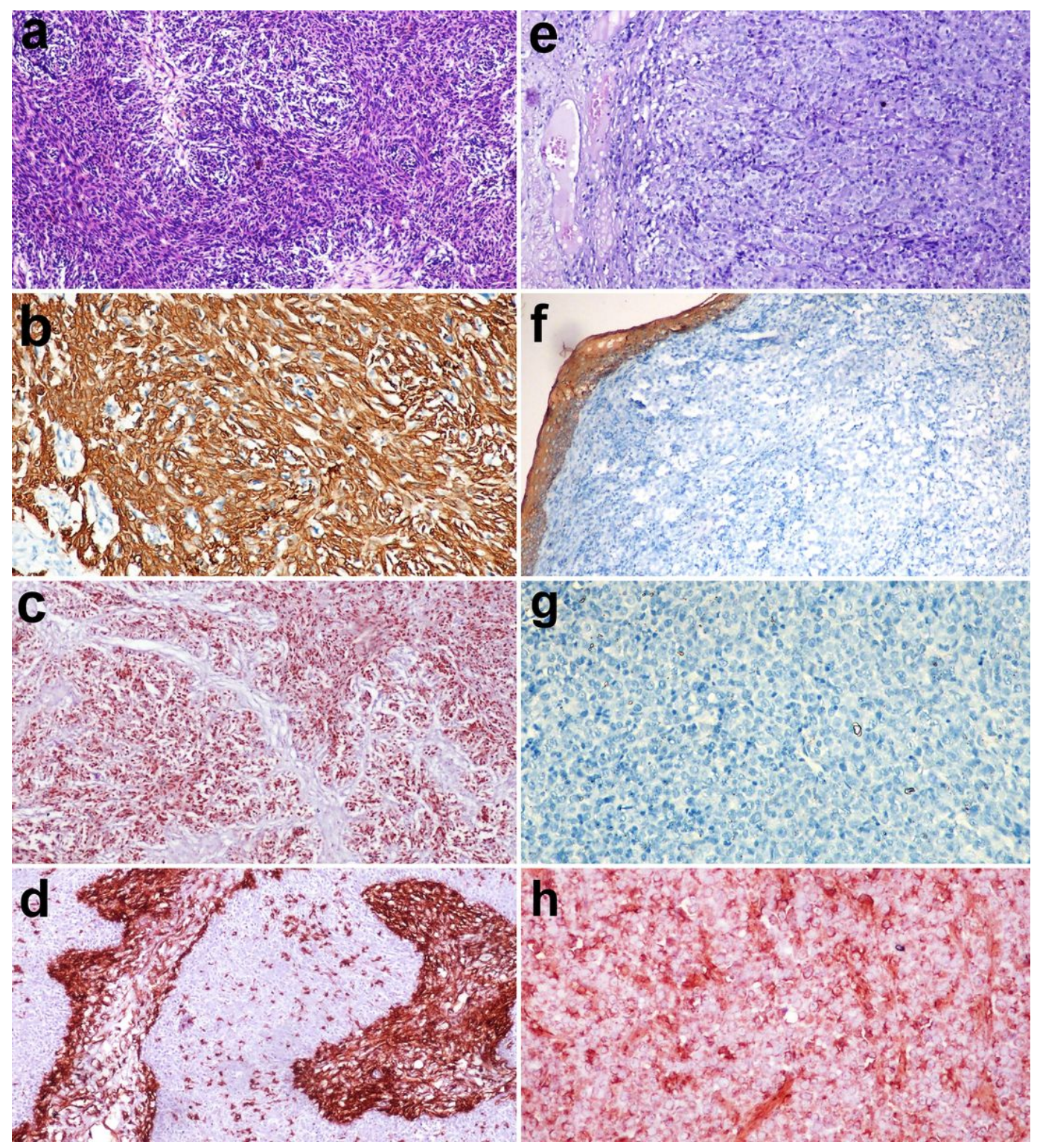

\section{Figure 6}

Canine mammary tumors. (a) complex carcinoma ( $\mathrm{H}$ and E stain X10) which show (b) strong positive expression of cytokeratin (X20) (c) moderate expression of P63, and (d) positive expression of vimentin in connective tissue (X10). Immunoperoxidase and hematoxylin counterstain (e) undifferentiated sarcoma ( $\mathrm{H}$ and $\mathrm{E}$ stain) which showed (f) negative immunoreactivity to cytokeratin and positive immunoreactivity in the overlying epidermis (X10), (g) negative immunoreactivity to P63, and (h) moderate expression of vimentin (X20). Immunoperoxidase and hematoxylin counterstain. 


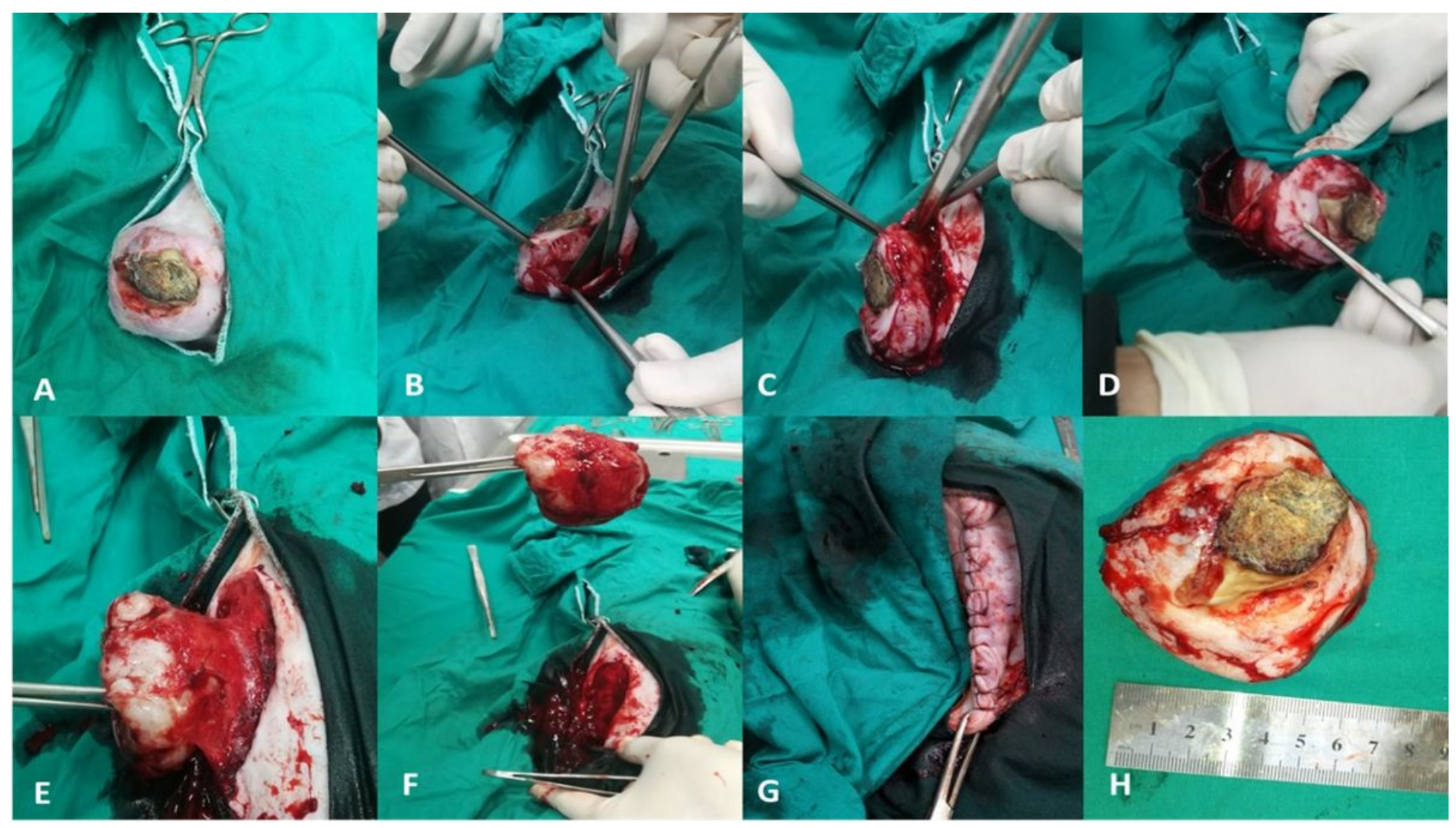

\section{Figure 7}

Photograph showing A) aseptic technique of site of operation B) elliptical incision of the skin over the nodule C, D) blunt dissection of the tumor using mosquito hemostats or scissors $\mathrm{E}, \mathrm{F}$ ) hemostasis by ligation of blood vessels around the tumor, and excision of tumor $\mathrm{G}$ ) subcutaneous tissue and skin were closed routinely $\mathrm{H}$ ) tumor after excision.

\section{Supplementary Files}

This is a list of supplementary files associated with this preprint. Click to download.

- AuthorChecklistFull1.pdf 